\title{
Academic Mobility, Transnational Identity Capital, and Stratification under Conditions of Academic Capitalism ${ }^{1}$
}

Terri $\mathrm{Kim}^{2}$

University of East London, U.K.

\begin{abstract}
Academic mobility has existed since ancient times. Recently, however, academic mobility - the crossing of international borders by academics who then work 'overseas' - has increased. Academics and the careers of academics have been affected by governments and institutions that have an interest in coordinating and accelerating knowledge production. This article reflects on the relations between academic mobility and knowledge and identity capital and their mutual entanglement as academics move, internationally. It argues that the contemporary movement of academics takes place within old hierarchies among nation states but such old hierarchies intersect with new academic stratifications which will be described and analysed. These analytical themes in the article are supplemented by excerpts from interviews of mobile academics in the UK, USA, New Zealand, Korea and Hong Kong as selected examples of different locales of academic capitalism.
\end{abstract}

\section{Keywords:}

academic mobility, academic capitalism, knowledge economy, otherness, stranger, transnational identity capital

\section{Introduction}

Academic mobility has existed for a long time, but it has become more systemic (Kim 2007; 2009) given the rise of academic capitalism (Slaughter \& Rhoades 2004; Münch 2014; Cantwell \& Kauppinen 2014) and the continuing expansion of higher education (Scott 1998; Marginson 2016). Academics, as a key part of the global transfer and production of knowledge, have become important to governments and universities that compete internationally. In turn, crossborder mobility and migration exposes academics to new contexts that can lead to new knowledge creation (Kim 2007; 2009; 2010; 2014).

\footnotetext{
${ }^{1}$ I thank the editors of this Special Issue and the reviewers for their valuable comments.

2 Email: t.c.kim@uel.ac.uk
} 
To be published in Higher Education Special Issue: The New Political Economy of Higher Education: Market logic, performance based stratification and neo-feudal hierarchies, edited by Tilman Reitz et. al. DOI: 10.1007/s10734017-0118-0

However, what is happening is complex. The contemporary globalisation of academic capitalism led by the Anglo-American linguistic and epistemic hegemonies has stratified national higher education systems and universities across the globe while it does not eliminate the national labour markets and career structures (Kim 2007; Marginson 2007). Academic migrations are especially subject to national particularities and institutional contingencies - including informal, implicit rules of the game as well as legal rules and conditions of employment (Musselin 2005; Kim 2007; Marginson 2007; Bauder 2015).

This article will show some of that complexity by highlighting the cultural dimensions of transnational academic mobility, knowledge and identity capital and their mutual entanglement in different contexts of academic capitalism and stratification.

It will be argued, first, that the contemporary movement of academics takes place within old hierarchies among nation states but such old hierarchies intersect with new academic stratifications. The article will also show some of the relations between academic mobility and different types of knowledge as 'capital'. It will define the concept of 'capital' and suggest 'transnational identity capital' - and illustrate the theme - as intimately related to the social process of academics crossing international borders. It will briefly discuss the relations between intellectuality and strangerhood (Pels 2000) and the notion of paraiah academics (Kim 2007; $2009 ; 2010 ; 2014)$. These analytical themes in the article are supplemented by excerpts from interviews of mobile academics in the UK, USA, New Zealand, Korea and Hong Kong. The article will offer an interim Conclusion with some post-hoc insights and reflection.

The article will begin by contextualising academic mobility and academic capitalism, and then focus on the patterns of and constraints on academic mobility currently.

\section{Academic mobility and academic capitalism}

While American universities are leading the international higher education market and enrolling unprecedented numbers of foreign students, the European Union as a regional bloc shares half of the international higher education market (in terms of the number of international students). The European Union has consistently emphasised its intention to become the most competitive 'knowledge economy' in the world. The UK Higher Education White Paper presented in May 2016 is also entitled 'Success as a Knowledge Economy: Teaching Excellence, Social Mobility and Student Choice' (BIS 2016, emphasis added).

The ideology of a knowledge economy that has exalted the role of higher education, however, implies that the domain of knowledge production should be thought of within an economic perspective: homo academicus modelled after homo economicus (Lorenz 2010): i.e., the value of 
To be published in Higher Education Special Issue: The New Political Economy of Higher Education: Market logic, performance based stratification and neo-feudal hierarchies, edited by Tilman Reitz et. al. DOI: 10.1007/s10734017-0118-0

knowledge production is increasingly defined by economic relevance and closely tied to the creation of revenue.

In practice, then, academics have become subject to administrative scrutiny ${ }^{3}$ which assesses their contribution to economies (Deem 1998; Cowen 2007; Rosinger et.al. 2016). One example is the UK's Research Excellence Framework (REF). Within what Lyotard (1984) has called the 'mercantilization of knowledge' (Lyotard 1984), the core of academic commitments is being shifted, through 'quality control' systems, towards and by a world defined by markets.

This transformation of the status of knowledge and higher education has been conceptualised as 'academic capitalism' (Slaughter \& Leslie,1997; Slaughter \& Rhoades 2004). Münch (2014) has shown that the rise of academic capitalism in Germany, the UK and the USA has led to a strong tendency toward uniformity of research and a loss of autonomy. It is argued that these rules of competition between entrepreneurial universities for capital accumulation and the rules that determine the competition between researchers for reputation exemplifies the illusio of the performance-based allocation of research funds that would last only as long as the actors allow themselves to be led by this view of reality (Münch 2014).

It is in this ideological and economic context that transnational ${ }^{4}$ academic mobility and migration ${ }^{5}$ has become more visible. This can be at least partly explained by different forms of increased competition - competition between research projects and institutions for international recruitments of students and staff, policies for technological innovation, and also individual academics' career development strategies.

Academic research communities have always stretched across conventional national and cultural boundaries, but their dynamics have been transformed, notably in Europe. The EU has consistently promoted academic mobility as a major policy priority for economic competition in the wider global market (European Union 2011). In the EHEA and ERA, mobility has become an important criterion for evaluating academic careers (Schiemeier 2011; Carroza and Minucci

\footnotetext{
${ }^{3}$ According to the HESA data in 2015, administrators now outnumber academics at more than two-thirds of UK universities (Jump, Times Higher Education September 3, 2015). This growth in the proportion of administrators and 'career managers' - often without serious academic backgrounds or experience - employed by universities has pushed up costs and corrupted universities' scholarly missions (Ginsberg 2011).

${ }^{4}$ I use the term 'transnational' academic mobility to highlight the idea of academics moving 'between' or 'above' or, in simple words 'across' territorial boundaries. So the emphasis is on individuals and movements which are occurring in 'transnational space' and not necessarily as part of official inter-action between nations. Thus, transnational should be differentiated from the conventional understanding of 'inter-national' (Kim, 2009, p. 395).

${ }^{5}$ Academic mobiity and migration are not the same but share the crossing of territorial borders. Academic mobility includes short-term visits, while academic migration is more specifically referring to employment status.
} 
To be published in Higher Education Special Issue: The New Political Economy of Higher Education: Market logic, performance based stratification and neo-feudal hierarchies, edited by Tilman Reitz et. al. DOI: 10.1007/s10734017-0118-0

2014). The existing literature on academic mobility more often than not emphasises mobility as a structural necessity (and thus tends to neglect its 'darker aspects' (Teichler 1996, p. 347; Bauder 2015)). As part of HE policy, 'excellence' initiatives have been launched at both supranational and national levels in Europe and Asia, which have led to strategic promotion of academic mobility and international academic migration in different frames and contexts: e.g. the European Excellence Initiative (EIE); Exzellenzinitiative in Germany; Programme d'Investissement d'Avenir in France; Research Excellence Framework (REF) in the UK; Brain Korea 21 and the World Class University Project in South Korea; Centre of Excellence (COE) and the Super Global Universities Project in Japan; Project 211 and 985, and 1,000 Talent Plan in China (Cheng, et. al. 2014).

The next section will examine more closely such new academic mobility and migration patterns and constraints.

\section{Academic mobility patterns: constraints and new stratifications}

In both the EU and the OECD, the immigrant population has grown by more than 30 per cent since 2000 (OECD, 2015), and the proportion of migrants with higher degrees is on the rise in the OECD area. In the OECD area, the five largest highly educated migrant populations are from India, the UK, the Philippines, China and Germany (OECD 2013), which confirms that highly skilled migrants are not moving vertically from the South to the North, and the patterns of transnational mobility and migration are becoming more complex.

When it comes to academic migration, in particular, it is equally important to note that academics do not move for purely economic reasons. Academic migration needs to be categorised differently from the ordinary economic migration (Bauder 2015). In my research, I have argued that transnational academic mobility and migration are more often shaped by the intellectual centre/periphery relationships rather than merely directed by pure economic incentives (Kim 2010). Similarly, for the so-called 'Creative Class' (Florida, 2014), lifestyle incentives (including diversity, community, identity and vibe) are considered far more important than economic incentives/ employment opportunities (Florida 2004, p. 7; p. 224).

However, there are still old hierarchies in the world society of (nation) states, often determined by ethnic identities and national citizenships - which are most acutely pronounced in the processes and consequences of transnational mobility and migration.

For instance, in Korea which maintains strong ethnonational homogeneity, a large-scale recruitment of international academics has been promoted through the Korean government's World Class University (WCU) project to make up a façade of internationalisation and compete in the world university rankings. However, this policy is in fact doubly discriminatory for both 
non-Korean and native Korean academics. For example, a leading international university in Seoul recruits only non-Korean nationals to academic posts. No Korean national, however excellent he or she may be as an international scholar working abroad, is eligible to apply, unless of course they give up their Korean nationality (Kim, 2011).

However, differentiation based on ethnic identity/national citizenship is not simple in major immigration countries: e.g. in the United States, many foreign workers would intend to gain US citizenship eventually, and yet there is still a strong (and unique) legacy of racial and ethnic diversity and conflict in the country. In Europe, the picture is far more complex given the free movements protected by the EU law (especially in the Schengen zone).

Furthermore, in the world of academic capitalism, such old hierarchies based on ethnic/national identities intersect with new academic stratifications, where institutional rent-seeking, reputational struggles and the dynamics of status attainment (Reitz 2017) re-position mobile academic individuals beyond the conventional boundaries and hierarchies determined by their national citizenships.

I believe this has significant implications for the state and future of knowledge production especially given the rise of nationalist sentiments and the probable implications of 'Trumpism' in the USA and 'Brexit' in the UK.

For instance, Duncan Haldane, a British Nobel laureate in physics at Princeton University says in the aftermath of the Brexit referendum:

I was seriously considering coming back a few years ago. It was suggested it might be possible to get one of these $€ 5 \mathrm{~m}$ ERC grants. That's much better support than I can get here. These grants are specifically aimed at bringing established people back. Without that it makes it more difficult for people to come back.

(Hannah Devlin, 'Brexit not good news for British science warn Nobel laureates' The Guardian, 6 October)

His initial move to the US was in the 1980s prompted by the Thatcher government squeezing funding for 'curiosity-driven' scientific research. He says "there was a depressing atmosphere in British science at the time because of stupid government ideas that one should do something 'useful'. They wanted to fund research into turbulence in North Sea gas pipes - an idea that I found pretty depressing." (ibid).

The following comments made by Johannes Angermuller, a German Professor at the University of Warwick in Coventry, England and the École des Hautes Études en Sciences Sociales (EHESS) in Paris, France also tell us how transnational mobile academics are being positioned after the 
To be published in Higher Education Special Issue: The New Political Economy of Higher Education: Market logic, performance based stratification and neo-feudal hierarchies, edited by Tilman Reitz et. al. DOI: 10.1007/s10734017-0118-0

Brexit referendum - especially after the UK Prime Minister Theresa May's controversial remark, "if you believe you are a citizen of the world, you are a citizen of nowhere", made at the Tory conference held on 5 October 2016.

The UK government has decided that EU citizens will no longer have an automatic right to live and work in the UK... Yesterday, I heard from the university's Vice Chancellor that we are encouraged to apply for UK passports because of the coming visa restrictions. However, getting a passport is a long and costly procedure and it has become more difficult every year... The problem is that I am often 'nowhere'. Most of my colleagues are 'nowhere'. Most of my friends are from 'nowhere' and much of my work is 'nowhere'. And I admit that, as a proud citizen of the world, I have always loved and I will love to go, live and work 'nowhere'.

(Facebook posting on 7 October 2016: https://www.facebook.com/johannes.angermuller?fref=ts).

Currently the situation is growing more complex - not least for practical reasons.

How can some of these complexities be theorised? The following section will look at the UK context, in particular, to highlight the intricate relations of intersectionality and stratification.

The proportion of foreign academics working in British universities has continued to increase. In 2007, 27 per cent of full time academic staff appointed at British universities were from outside the UK. It is estimated that the proportion of international academics employed in British universities will rise to 50 per cent by 2027 (Universities UK 2007). Overall the prospects of UK universities are increasingly depending on non-UK nationals/foreign academics for regeneration, which may be indicating the de-nationalisation of the (British) academic profession.

In terms of ethnicity, the proportion from Black and Minority Ethnic (BME) group ${ }^{6}$ who are non-UK nationals is 28 per cent among academics working in British universities. It is 7 per cent among UK nationals (HESA 2015: https://www.hesa.ac.uk/stats-staff). In Oxford, the proportion of BME non-UK nationals among the academic and research staff (combined) is 18 per cent compared with 9 per cent of UK nationals (University of Oxford, 2016, p. 29).

The difference is interesting. Fernando and Cohen (2016) suggest - based on their interviews conducted with 32 Indian academic migrants working in science and engineering departments of a UK university - that 'ethnic capital' tied with cultural knowledge and networks can be used to move up the career ladder. The Indian academics interviewed by Fernando and Cohen (2016)

\footnotetext{
${ }^{6}$ BME staff are generally under-represented at senior levels in UK universities (see Bhopal and Jackson, 2013).
} 
To be published in Higher Education Special Issue: The New Political Economy of Higher Education: Market logic, performance based stratification and neo-feudal hierarchies, edited by Tilman Reitz et. al. DOI: 10.1007/s10734017-0118-0

were proactively complying with the new 'rules' of the game that promote 'performativity'. Fernando says: "If you are comfortable with the new rules, you are more likely to be able to play the game better than those who have not embraced the rules" (https://www2.warwick.ac.uk/newsandevents/pressreleases/research finds migrant/). Fernando and Cohen (2016)'s research findings suggest that single-mindedness and competitiveness, influenced by early experiences of getting through challenging circumstances, enabled these Indian academics to focus exclusively on publishing and research income, especially as the status associated with senior positions is very important in their country of origin. They conclude that internationally mobile migrant academics have an advantage in research-heavy universities in general, and the 'market-driven' UK universities have provided new kinds of opportunities for migrant academics to build their careers.

Interesting counter-point is offered by Sang, Al-Dajani and Özbilgin (2013) who suggest that first-generation migrant academic women professors - at the intersection of gender and ethnic disadvantage (hence the cumbersome theoretical term' intersectionality') - thus occupy the status of "double outsiders". However, the people they interviewed were also able to mobilise resources which enabled them to reach the position of full professor.

Contrary to expectations, migrant women academics display greater levels of agency, connectedness, and entrepreneurial flair to mobilize their varied resources in order to achieve career success. Intersectionality of otherness opened up possibilities for this group of professors to transcend some of the embedded assumptions of gender and ethnic privilege at work.

(Sang, Al-Dajani and Özbilgin, 2013: 160-1; italics added)

Overall, then the pattern of transnational academic mobility, academic migration and knowledge creation is facilitated by the new neoliberal corporate norms and practices in universities. Now knowledge can be strategically transferred (and transformed by mobile academics) to establish a competitive advantage and possibly generate 'profits' in quasi- markets.

Transnational mobile academics in the market framed university seem to have used relative advantages - that is 'differences' have been used as potential competitive advantages. My previous research (Kim, 2009; 2010; 2014) has highlighted the significant position and role of mobile academics as an intellectual 'stranger' (invoking Simmel). The stranger is the synthesis of the totally uprooted wanderer and the totally rooted individual. Orlando Patterson (1977) in Ethnic Chauvinism argued that Simmel's conceptualisation of 'a stranger' is relevant: the stranger helps to make 'objectivity' possible:

In his isolation he creates. And to these exilic creations humanity owes almost all its great developments. It is no accident that so many of the greatest minds in the history of 
To be published in Higher Education Special Issue: The New Political Economy of Higher Education: Market logic, performance based stratification and neo-feudal hierarchies, edited by Tilman Reitz et. al. DOI: 10.1007/s10734017-0118-0

humanity have been exiles, whether within or without the societies of their birth. No prophet ... is accepted in his own country.

(Patterson, 1977, p. 19)

Invoking what Lévi-Strauss calls "the shamanistic complex", Patterson (1977) notes the mode of being of the sorcerer lies parallel to that of the nonconforming individualist in civilized society (pp.19-21). That is a very dramatic claim. Here I would merely suggest that the position of a 'stranger' becomes a potential competitive advantage to generate new knowledge capital.

However, given the wide spectrum of transnational mobile academics across space and time, it is not simple to generalise about how they are actually positioned. My initial proposition is that an important way to see the process of academic mobility entwined with that of knowledge creation is through different types of knowledge as capital.

\section{Intricate relations of academic mobility and different types of knowledge as capital}

Earlier (Kim, 2014), I argued that different types of knowledge carried by mobile academics include not only scientific knowledge (Wissenschaften) but also world views (Weltanschauungen). According to Polanyi (1966), all knowledge is rooted in tacit knowledge. He argued that tacit knowledge - tradition, inherited practices, implied values, and prejudgments - is a crucial part of scientific knowledge. Similarly, Collins (1993; 1995) also suggested that most of what we once thought of as the paradigm case of 'unsocial' knowledge - science and mathematics - has turned out to be deeply social.

Noting the complex, tacit, and mobile nature of knowledge and the knowledge creation process, I am suggesting that (i) new forms of knowledge emerge as a result of academic mobility; and (ii) they become transnational capital. This raises some fundamental issues around 'positional knowledge' and 'creative knowledge' generated by individual mobile academics, and their relations in the contemporary university contexts. To approach these issues, I do not use Bourdieu; but C. Wright Mills (1959)' The Sociological Imagination, and Paul Ricoeur's Time and Narrative (1984) and 'Narrative Identity' (published as Oneself as Another 1992). The emphasis, by Mills, is on getting at the intricate connection between the patterns of individual lives and social structures and movements, and the course of world history in order to "understand the larger historical scene in terms of its meaning for the inner life [as embodied subjectivity] and the external career of a variety of individuals" (Mills 1959, p. 5). Ricoeur makes the similar general point in different vocabulary- historical time becomes human time "to the extent that it is articulated through a narrative mode (Ricoeur, 1984, p. 52). 
To be published in Higher Education Special Issue: The New Political Economy of Higher Education: Market logic, performance based stratification and neo-feudal hierarchies, edited by Tilman Reitz et. al. DOI: 10.1007/s10734017-0118-0

Earlier, I used this perspective to sketch the biographical narratives of 50 mobile academics collected across disciplines and career stages in a period of seven years (2008-2015). Through biographical narrative analysis, I tried to show academic mobility as an 'ontological condition' and how socio-spatial transfer of knowledge is followed by the transformation of knowledge into transnational capital (Kim, 2010). As a conceptual analytical tool, I coined the term 'transnational identity capital' to explicate how mobile academics reflexively use their embodied positional knowledge in their geographical and institutional border-transcending and intellectual bordertransgressing activities. It will be recalled that identity capital as initially defined by Côté \& Levine (2008) includes cultural capital as well as many other elements that are specific to membership in any type of social culture. Identity capital operates to validate group membership or preserve a self-definition (Côté \& Levine, 2008). Identity capital is distinguished from social capital which in general refers to bonding and network power. Côté (2005) argues that it is important to:

"understand the attributes of the people potentially sharing the bonds, in part because those attributes can determine who is allowed to share the bonds, especially as these attributes relate to social identities based on race, gender and the like.... The process of identity capital acquisition describes how the individual invests in a certain identity (or identities) and engages in a series of exchanges with others in a variety of contexts (only some of which are economic)." (Côté, 2005: 225-6; emphasis added).

Thus, starting from this definition of identity capital by Côté \& Levine (2008) and Côté (2005), my concept of transnational identity capital represents attributes associated with sets of personal psychosocial competencies in negotiating their ways in the transnational space - especially in the absence of tangible cultural guidance and social norms. Transnational identity capital then becomes a critical reflexive hexis. It is an authentic individual asset, not reproducible. It is more than cultural capital and social capital in the specific context of national society - for example, in the French context, Bourdieu (1977) claimed that the accumulation of cultural capital is used to reinforce class differences. That point was well made for France.

In contrast, however, transnational identity capital transcends national cultural boundaries. Transnational identity capital is highly tacit, embodied, travelled knowledge. It is generic competences to engage with 'otherness" ${ }^{7}$, which enables mobility in and out of different habitus between and above inter-national territorial boundaries. It is a mode of cosmopolitan positioning to forge and sustain multi-stranded social relations, which makes it easy to move in and out of diverse groups and contexts - including ethnic and national sub-cultures. Accordingly, my conceptual framework is not limited to Bourdieu's well-known (and conventional) distinction

\footnotetext{
${ }^{7}$ The concept of 'otherness' here is taken as the quality that someone or something has, which is different from himself/herself or from the things that he/she has experienced (Kim, 2010, p. 583). I use the term 'cosmopolitan' simply as 'a perspective, a state of mind, or a mode of managing meaning' (Hannerz, 1996, p. 102) as opposed to the parochial and localised boundaries (Kim, 2010, p. 584).
} 
To be published in Higher Education Special Issue: The New Political Economy of Higher Education: Market logic, performance based stratification and neo-feudal hierarchies, edited by Tilman Reitz et. al. DOI: 10.1007/s10734017-0118-0

between habitus/hexis and capital. Mobile academics whose position can be 'cosmopolitan' with 'transnational identity capital' are not limited to a certain class-specific boundary.

In short, my conceptual definition of 'transnational identity capital' is not 'class-bound', although it can be 'class-relevant' as enhanced by symbolic capital, and objectified, institutionalised capital. The biographical narratives presented in the next section explore how mobile academics are positioned in different places.

\section{Mobile academics in difference places of academic capitalism - reflecting on their experiences}

Contemporaneously the highly skewed process of academic knowledge production and extremely competitive up-or-out nature of academic career development has become more tied to neoliberal performativity regimes (Shore \& Wright 1999; Ball, 2012) ${ }^{8}$, and this is more acutely experienced by mobile academics as crossing both inter-national and academic cultural boundaries.

For instance, post-doctoral and early-career researchers seek international experience strategically to render them more competitive in the academic labour market. In this way, international experience can serve as a distinct form of capital for transnational mobile academic career development (Bauer, et. al. 2016; Teichler, 2006). The excerpt (below) from my interview with a French social scientist (of mixed ethnic background) working as a postdoc in the USA, UK, and the Netherlands explains how she moves in and out of the multiple, multinational academic boundaries, which has also determined her choice of research subject:

In the US, I was doing a postdoc and most of us were internationals, and worked really hard for a predominantly US faculty. This could be for a variety of reasons: postdocs tend to move like me or maybe that the scarcity of jobs had little prospects to move up it seemed. This two-tiered system was less visible to me in the UK (or maybe I did not notice it at the time). I am new to the Netherlands so I can't tell. They seemed to be pretty open despite recent changes in the law to make it harder for foreigners to work in the Netherlands...

\footnotetext{
${ }^{8}$ There is a radical shift in the mode of academic knowledge production. The new paradigm, according to Shore and Wright (1999: 559) is 'the re-invention of professionals themselves as units of resource whose performance and productivity must constantly be audited so that it can be enhanced'. Stephen Ball in his article on performativity and commodification admits that the neoliberal aspects of reform have required him to make himself calculable rather than memorable (Ball, 2012).
} 
... Generally speaking I constantly feel aware of my mixed ethnic background and the culture that comes with it, and how it impacts on the audience to know how I can be authoritative in front of a predominantly male, white and English speaking audience.

(Excerpted from the interview with a French female academic (with mixed ethnic backgrounds) working in the UK, USA and the Netherlands, Feb. 2012).

Other penetrative social constraints of the academic migrant's interstitial position and the experience of cultural schism between different academic traditions, in the neoliberal performativity regime are powerfully expressed by Bönisch-Brednich, a German Professor of Anthropology in New Zealand:

Having learnt to be 'the Other' means that I can never be Kiwi, nor do I aspire to be; after some years, however, I and other academic migrants like me may even become incapable of re-immersing ourselves in the academic world from which we came. We become the Other in both worlds and as a result will always be reflexive about our place in academic environments...

... The pressures to become a 'self-managing academic' who adheres to business thinking are difficult enough for locals who have been slowly coerced into the performativity regime... As a [German] academic migrant, this often creates another layer of culture shock, experienced as a deep intrusion into my academic identity. Moreover, it is an imposition of another learning process: a third birth, a re-making of the academic self into a participant in an entrepreneurial system of producing and selling knowledge. Resisting this often means a slow or sudden professional death...

(Bönisch-Brednich, 2010: 170).

Similarly, Professor Galin Tihanov, a Professor of Comparative Literature at Queen Mary University London, expressed his transnational academic identity:

It is less my nationality [Bulgarian] and national culture and more a broadly defined regional cultural characteristic that matter... I am the product of an education that was very much Germanic in the best sense of the word. So I do have a great deal of respect for ideas and 'pure knowledge', and I am less infected with pragmatic attitudes to scholarship, although I have come to appreciate their strengths in recent years...

.... The only situation when I could possible get a feel of 'foreignness' is when I am in a management meeting, surrounded by people who take things all too seriously, without a sense of distance, sober reflection, or critical examination of the system and its dogmas. But this lack of critical distance could be found amongst people from different cultures, 
To be published in Higher Education Special Issue: The New Political Economy of Higher Education: Market logic, performance based stratification and neo-feudal hierarchies, edited by Tilman Reitz et. al. DOI: 10.1007/s10734017-0118-0

it is not a national trait; it is a specific mentality that seems to be proliferating in the new academic culture.

(Excerpted from my research interview (by email) with Professor Galin Tihanov, 23

December 2011).

There is sharp counterpoint here with Karl Popper (1902-1994) - who also wrote about his position as an 'intellectual stranger' in New Zealand - when he moved from the University of Vienna to Canterbury University College where he taught philosophy. During his time in New Zealand (1937-45), he wrote his magnum opus, The Open Society and Its Enemies (1945):

Libraries were severely limited and I had to adjust myself to whatever books were available. I had a desperately heavy teaching load, and the university authorities not only were unhelpful, but tried actively to make difficulties for me. I was told that I should be well advised not to publish anything while in New Zealand, and that any time spent on research was theft from the working time as a lecturer for which I was being paid.

(Popper, K. 1976: 119).

Another distinctive example of transnational mobile academic intellectuals during the inter-war period is Moritz Bonn (1873-1965), who was a German Jewish academic exile with the prominent academic and government networks in both the UK and USA. He was successfully integrated into the host society - according to his own expression, moving from the position of a 'bloody foreigner' to that of a 'distinguished' foreigner. He later wrote about his interstitial position in the London School of Economics Alumni Magazine in 1946: "I have always been far closer to the English way of thinking than most exiles. In fact, I have never felt like one" (Clavin 2002, p. 33).

The in-between positions of a stranger confirm the strong non-conforming individualist identity with the specific attitude of "objectivity", which Simmel (1908) tells us, makes him/her a freer man/woman. Patterson (1977) also emphasises the theme of being "deviant, individualist, exile, creator and revolutionary", among the motives which made academics move away from their home countries. He argues that he or she [mobile academics] is "above all else human, wholly human, who seeks freedom from all constraints... it is the ethnic chauvinist who isolates himself from the rest of humanity" (p. 22).

The following is an excerpt from an interview with an Australian male professor based in England, narrating why he moved and how his work is related to that. 
I had been on top of the field in Australia for more than a decade but I needed to move out of my comfort zone, become stimulated by more frequent encounters with a larger intellectual pool, develop and test my ideas in a more demanding intellectual environment. I was bored in Australia as the policy and intellectual climate in higher education were not moving. Most of my ideas and best work were overseas oriented already. Though I could have kept working globally from Australia. A large part of intellectual life in many countries is now carried by non nationals, and cross-border collaborations...

(Excerpt from the interview with an Australian male professor working in England, October 2015)

Similarly, a British male professor based in Beijing highlights the main reason for moving to overseas institutions:

Many, many years ago, when I was being offered an excuse as to why I should not be promoted to the rank of professor, I was told, "You have an international reputation, but not a national reputation". This was obviously with reference to the ranking system used in the RAE/REF, and since it was a hierarchy with international reputation at the top, this statement was clearly nonsense. But it reflects a partial truth for me, that I have always felt better appreciated outside my own institution, and even outside my own country, than inside it.

(Excerpt from the interview with a British male professor working in Beijing, June 2015; italics added).

A similar remark was made by the well-known British academic migrant, Nial Ferguson at Harvard. Despite holding a senior academic post at Oxford, Ferguson actively wanted out of the British academic scene:

As a financial historian, I was quite isolated in Oxford - British historians are supposed to write about kings - so the quality of intellectual life in my field is much higher at Harvard. The students work harder there... I am over-industrious, so I don't feel quite such a deviant in America as I did in England. The time I spent in England now begins to feel like a detour. I realised last year I was never going to come back here to live.

(Jo Lo Dico, 'Politics, prestige and power players in New England' Evening Standard, 7 December 2015) 
However, transnational academic mobility is about situated cultural practices so that cultural logics work differently in non-Anglo contexts and non-English speaking academic systems. South Korea, for instance, has a strong ethno-national habitus, and there is lack of intercultural engagement and equity, which inconvenience and disadvantage foreign academics inside academe.

A Korean-American, male Professor having been working at one of the major universities in Seoul for more than 10 years, whom I interviewed in $2011^{9}$, says:

I do not feel a strong attachment to either one country or another. This allows a certain amount of academic and cultural freedom to create and explore third cultures - which carries with it the price of an inherent instability and lack of academic or social support. This increasing number of foreign academics is an inevitable result of the demand not only for courses taught in English or other languages, but for alternative perspectives and expertise".

However, what he has experienced is quite the opposite to the general expectation of internationalisation. According to his expression, foreign professors are to be "kept in their place": "A general ethos that permeates the work culture in my school is that foreigners are not the experts. We are merely hired hands to do the work that locals are unable to do."

A Canadian academic who had worked in a Korean university English Department and has recently returned to Canada describes the working condition of Korean university and culture as "the Golden Handcuffs".

You're trapped in an extremely lucrative dead-end job. There is no room for advancement. When teaching in a Korean university, there quite literally is nowhere to go but sideways or down. It's impossible to get into any sort of admin [management] position.

(Blog: "Korean University Jobs: The Golden Handcuffs", August 30, 2015: http://teachinginkoreanuniversity.com/korean-university-jobs-the-goldenhandcuffs/)

In South Korea, foreign academics are, in general, excluded from academic management roles and university administrative businesses. This may be quite similar to the Japanese case (Mock, et. al., 2016) but it seems that there is more exclusive ethno-nationalism serving as boundaries of non-inclusion in Korean academic culture. My research (Kim, 2005; 2011) and more recently

\footnotetext{
${ }^{9}$ Some of my empirical research data is from my SRHE-funded research: 'Internationalisation, Mobile Academics, and Knowledge Creation in Universities: a Comparative Analysis', SRHE Research Award 2011/12.
} 
To be published in Higher Education Special Issue: The New Political Economy of Higher Education: Market logic, performance based stratification and neo-feudal hierarchies, edited by Tilman Reitz et. al. DOI: 10.1007/s10734017-0118-0

research by Stephanie Kim (2016) confirm the continuing institutional discriminations against foreign nationals in Korean academe. The system also makes it an obvious disadvantage for foreign academics to pursue a long-term career in Korean academe while perpetually replacing those who leave with new recruits (S. Kim 2016). According to Chosun Ilbo's report entitled 'Why Are Foreign Academics Running Away?' published on 24 December 2013, the proportion of foreign academics in four-year universities in Korea rose from 2.4 percent (1,021 people) in 2000 to 7.7 percent $(5,358)$ in 2013 . However, most of them tend to leave after just a few months of teaching there.

(http://english.chosun.com/site/data/html_dir/2013/12/24/2013122401784.html).

Similarly in Japan, a type of internationalisation promoted in the Japanese government's Super Global Universities programme is implicitly equated with 'Westernisation', focusing on the Anglosphere but intended primarily to serve Japan's national interests. The global and Japanese spaces will remain distinct. Jeremy Rappleye and Edward Vickers (2015) sharply criticise: "Indeed, those closely involved with the current reforms will quietly tell you how few highquality applications they are receiving for new 'international' positions. In this sense, Japan is getting exactly what it pays for."

(http://www.universityworldnews.com/article.php?story=20151103154757426).

In regard to the relationship between knowledge and identity, the following excerpt from the interview with a British male academic in Hong Kong reveals the significance of Anglo-ethnic identity and national cultural heritage in shaping the mobile academic's epistemic world regardless of mobility:

...[my work] demonstrates how reliant I am on an essentially Anglo-AustralianAmerican literature... I would not pretend to be as 'international' as some people like to lay claim to. In fact I think that sometimes being 'international' and having a 'global' perspective is over-emphasised, used as a bit of an empty boast and tends to devalue local knowledge and cognitive perspectives that cut across language/culture/nationality. That's my thought anyway. I guess I will always see myself as English and acknowledge that my cultural heritage is key in my work.

(Excerpted from the interview with a British male professor working in Hong Kong, July 2011)

In comparison, the Australian male professor in England, whose interview was cited earlier, narrates his positional identity and experience of how a stereotypical national identity is accorded to him: 
I always feel foreign here, and to some extent also 'Australian' in a way I did not feel in Australia, as Australia is firmly positioned here in terms of the colonial Britain/Australia relationship, in which Australia does not have a fully independent identity. This kind of 'Australian-ness' is forced on me, like discrimination on the basis of colour, it is not an identity that I choose. The colonial relationship is painful for me, to the point where I find myself stereotyping the 'English' in response. I will never feel comfortable in UK.

He then offers a comparative view on how different societies filter foreignness drawing on his biographical account of being a mobile academic in different national settings:

I do not have this problem anywhere else in the world, though many countries filter one's engagement in other ways - e.g. in the USA one is not othered as much as in UK, but only really accepted if one fairly fully integrates. Americans will welcome you into their society if you become American... In Japan one is always an honoured guest and no other role is possible... One thing none of them do without a big push is change themselves to accommodate difference. Japan is only the most extreme example of that problem, common everywhere.

(Excerpt from the interview with an Australian male professor working in England, October 2015, italics added.)

His comment on Japan echoes what has been discussed earlier on Korea - as both societies and their academic habitus sustain strong ethnonational cultural 'exclusivity' and 'resilience' in the process of globalisation of academic capitalism, and beneath the state-enforced internationalisation policies.

Overall these kinds of biographical reflections by transnational mobile academics illustrate how mobile academics are positioning themselves and being positioned. In the globalised norms of academic capitalism, universities are turning into transnational corporations and the façade of academic culture is represented by the discourse of "excellence".

It is in this context that the patterns of transnational academic mobility can be understood. However, the individual biographical narratives of mobile academics tell us the disparities and disjunctures and some of the costs of 'excellence', which include new and complex stratifications - not always congruent with the conventional understanding of the global university hierarchies and the new versions of academic identity in the process of residualizing academic capitalism.

\section{Conclusion}


To be published in Higher Education Special Issue: The New Political Economy of Higher Education: Market logic, performance based stratification and neo-feudal hierarchies, edited by Tilman Reitz et. al. DOI: 10.1007/s10734017-0118-0

Despite the surface similarities of policies, which promote academic mobility in many different places and international competition for global university rankings and hierarchies, the reception of academic migrants varies geographically and can be framed by quite specific local peculiarities: for example, 'ethnonationalism' as in Korea and Japan. The rules of stratification in academic capitalism are not transnational but 'place-bound'.

Mobilities also affect the person and create possibilities for the creation of new kinds of knowledge. The biographical narratives of transnational mobile academics collected in my research are obviously polysemic by nature. Nevertheless, I would argue that they entail an 'analogical unity of action' (Ricoeur 1992) embedded in academic mobility, which I recognise as an ontological condition. Of course, displacement is a common experience not just of academic migrants but of migrants in general. However, such displacements, for those who possess 'transnational identity capital' (as elaborated earlier), can be a vital catalyst to generate new knowledge through the process of displacement contributing to a 'creative destruction' and reconstruction of the paradigms of academic work. This is because transnational identity capital formation is itself the process of shifting from hard, scientific, explicitly codified knowledge to organic, intrinsic, implicit, reflexive, spatialised knowledge - namely embodied and encultured knowledge (Kim 2010).

Although the experiences of mobile academics would differ qualitatively (depending on where they stand at the intersection of multiple forms of 'otherness'), I would argue that successful transnational mobile academics, regardless of their gender, ethnic, national and social class backgrounds, tend to have a divergent and implicitly expansionist orientation and epistemic paradigms. This orientation is a reflexive; it is an in-between stance; and it hints at forms of the "objectivity" of an outsider, as sketched earlier.

In this regard, I think that a new 'transnational academic tribe and territory' is emerging and becoming more visible, which has some crucial implications of the minority-majority shift in the domain of knowledge creation.

This is very different from the conventional 'territory'-based academic-tribal characteristics illuminated first by Tony Becher in 1989 and subsequently with Paul Trowler in 2001. Instead of focusing on the territory of academic knowledge by disciplines, my research has explored mobile academics' embodied knowledge that is, their transnational identity capital.

'Embodied knowledge' as a matter of routines, habits, practices, skills, and non-deliberative actions generally has been discussed in phenomenology - e.g. by Husserl, Merleau-Ponty, and others, which has been taken up by contemporary sociologists such as Pierre Bourdieu. (Jensen and Moran, 2013, p. x). In Distinction: A Social Critique of the Judgement of Taste, Bourdieu (1984) articulates the "two principles of division which are at work in all class-divided societies the division between the dominant and the dominated, and the division between the different 
To be published in Higher Education Special Issue: The New Political Economy of Higher Education: Market logic, performance based stratification and neo-feudal hierarchies, edited by Tilman Reitz et. al. DOI: 10.1007/s10734017-0118-0

fractions competing for dominance in the name of different principles, bellatores (warriors) and oratores (scholars) in feudal society, businessmen and intellectuals now" (Bourdieu, 1984, p. 472). Bourdieu describes the opposition between the dominant and the dominated in terms of orthodoxy (possessing the capital relevant to set the rules of the field and habitus) and heresy (not possessing the relevant capital). The fields set the stage for struggle and direct the actors towards specific forms of struggle through the deep structure (doxa) that is agreement between all participants in the field. Bourdieu defines doxa as "a particular point of view, the point of view of the dominant, which represents and imposes itself as a universal point of view" (Bourdieu 1998, p. 57).

Although my conceptual use of 'capital' in this paper is not confined to Bourdieu's definition, I take this analogy by Bourdieu (1984) as a useful aperçu for thinking about the deep structure of academic capitalist societies and the division between different fractions competing for dominance in the new rules of performativity and stratification now.

What the illustrations from the lives of various academics reported above and the concept of 'transnational academic capital' suggest is that mobile academics could make - in themselves, in their assumptions, in their forms of intellectuality - a challenge to local forms of doxa, and hence more routinely than might be anticipated be a force for academic creativity at a time when academic engagement in the production of knowledge is governed by the performativity regimes (as doxa) - orchestrated by competitive nation states and transnational corporations which step up pressure on market-framed universities. The university as a corporate form (universitas) is now busy servicing other business organisations (as well as the defence establishment), dealing above all in intellectual property, intellectual capital, and knowledge as commodity. The orthodoxy in contemporary academic capitalist societies is clear now.

In this regard, I would suggest that transnational mobile academics bear witness to an historic process of global transformation of the archetype university, while struggling for 'excellence' at the intersection of the roles of 'businessmen' and 'intellectuals' - both competing for dominance in the name of different principles.

After all, the university is a site of both the establishment and pariah, which entails innate contradiction. The university as an institution is inherently conservative in nature and yet intellectual fields are not built by consensus but by creative destruction. Accordingly, I would suggest that the position of 'a stranger' by acquiring 'transnational identity capital' would enable academics - both mobile and immobile academics who stand at the intersection of multiple forms of 'otherness' - to professionalise strangerhood in knowledge creation as well as in institutional practices.

This is the hidden face of 'the internationalisation' of universities; and perhaps the general theme of 'otherness' and 'the stranger' has become more apt and more urgent than ever given the 
To be published in Higher Education Special Issue: The New Political Economy of Higher Education: Market logic, performance based stratification and neo-feudal hierarchies, edited by Tilman Reitz et. al. DOI: 10.1007/s10734017-0118-0

disturbing flashes of ethnocentrism and racism in the politics of the post-Brexit and pre-Trump periods, which may be marked as a new epoch of ethnic chauvinism and divisive nationalism.

\section{References}

Ball, S. (2012) Performativity, Commodification and Commitment: an I-Spy Guide to the Neoliberal University In British Journal of Educational Studies 60th Anniversary Special Issue 60(1), March, 17-28.

Bauder, H. (2015). The international mobility of academics: A labour market perspective. International Migration 53(1), February, pp. 83-96.

Becher, T. (1989) Academic Tribes and Territories: Intellectual Enquiries and the Cultures of Discipline, Buckingham: SRHE and Open University Press.

Bhopal, K. and Jackson, J. (2013). 'The experiences of black and minority ethnic academics: multiple identities and career progression.' Research Report funded by the EPSRC and University of Southampton, Equality and Diversity.

Bönisch-Brednich, B. (2010) Migrants on campus: becoming a local foreign academic. In Bönisch-Brednich, B. and Trundle, C. (Eds). Local Lives: Migration and the Politics of Place, Farnham: Ashgate, pp. 167-182.

Bourdieu, P. (1998). Practical Reason: On Theory of Action, Stanford, CA: Stanford University Press.

Bourdieu, P. (1984). Distinction: A Social Critique of the Judgement of Taste (Richard Nice, Trans. and Tony Bennett, Intro.), London and New York: Routledge.

Bourdieu, P. (1977). Cultural Reproduction and Social Reproduction. In Karabel, 1. and Halsey, A. H. (Eds). Power and Ideology in Education. Oxford: Oxford University Press.

Cantwell, B. and Kauppinen, I. (Eds). (2014). Academic Capitalism in the Age of Globalization, Baltimore: Johns Hopkins University Press.

Cheng, Y., Wang, Q., Liu, N. C. (Eds). (2014). How World-Class Universities Affect Global Higher Education: Influences and Responses, Rotterdam: Sense Publishers.

Clavin, P. (2002). A Wandering Scholar in Britain and the USA, 1933-45: The Life and Work of Moritz Bonn, The yearbook of the research centre for German and Austrian Exile Studies: 
To be published in Higher Education Special Issue: The New Political Economy of Higher Education: Market logic, performance based stratification and neo-feudal hierarchies, edited by Tilman Reitz et. al. DOI: 10.1007/s10734017-0118-0

Refugees from the third Reich in Britain, Vol. 4, 27-42.

Collins, H. (1993). The Structure of Knowledge In Social Research, 60, Spring, 95-116.

Collins, H. (1995). Humans, machines, and the structure of knowledge In Stanford Humanities Review, 4, no. 2: Constructions of Mind. A special issue edited by Stefano Franchi and Güven Güzeldere (http://www.stanford.edu/group/SHR/4-2/text/collins.html).

Côté, J. E. (2005). Identity capital, social capital and the wider benefits of learning: generating resources facilitative of social cohesion, London Review of Education 3(3), November, pp. 221237.

Côté, J. E., \& Levine, C. G. (2008). Identity Formation, Agency, and Culture: A Social Psychological Synthesis, Mahwah, NJ: Lawrence Erlbaum Associates, Inc. Publishers.

Cowen, R. (2007). Effectivity, Performativity and Competition: Forms of Domination in Comparative Perspective in H-G. Kotthoff and S. Moutsios (Eds). Education Policies in Europe: Economy, Citizenship, Diversity, Münster: Waxmann, 89-100.

Deem, R. (1998). 'New managerialism' and higher education: The management of performances and cultures in universities in the United Kingdom, International Studies in Sociology of Education, 8(1), 47-70.

Department for Business, Innovation \& Skills (BIS) (2016). Success as a Knowledge Economy: Teaching Excellence, Social Mobility and Student Choice. The Higher Education White paper presented to Parliament by the Secretary of State for Business, Innovation and Skills by Command of Her Majesty, May 2016 (https://www.gov.uk/government/uploads/system/uploads/attachment_data/file/523546/bis-16265-success-as-a-knowledge-economy-web.pdf)

Devlin, H. (2016). Brexit not good news for British science warn Nobel laureates, The Guardian, 6 October 2016: https://www.theguardian.com/science/2016/oct/06/brexit-not-good-news-forbritish-science-warn-new-nobel-laureates .

Dico, J. L. (2015). Politics, prestige and power players in New England: From Tessa Jowell to Ed Balls, a growing number of Westminster's biggest personalities are finding sanctuary in a plum role at Harvard, Evening Standard, 7 December 2015: http://www.standard.co.uk/lifestyle/london-life/from-tessa-jowell-to-ed-balls-englandspolitical-power-players-are-finding-sanctuary-at-harvard-a3131246.html).

European Union (2011). Europe 2020 Flagship Initiative Innovation Union, Luxembourg: Publications Office of the European Union. 
To be published in Higher Education Special Issue: The New Political Economy of Higher Education: Market logic, performance based stratification and neo-feudal hierarchies, edited by Tilman Reitz et. al. DOI: 10.1007/s10734017-0118-0

Fernando, W. D. A. \& Cohen, L. (2016). Exploring career advantages of highly skilled migrants: a study of Indian academics in the UK, International Journal of Human Resource Management 27(12), 1277-1298.

Florida, R. (2004). The Rise of the Creative Class, New York: Basic Books.

Ginsberg, B. (2011) The Fall of the Faculty, Oxford: Oxford University Press.

Hannerz, U. (1996). Transnational connections. London: Routledge.

Jensen, R. T. and Moran, D. (Eds). (2013). The Phenomenology of Embodied Subjectivity, Cham, Switzerland: Springer.

Jump, P. (2015) Academics in the minority at more than two-thirds of UK universities, Times Higher Education, September 3, 2015: https://www.timeshighereducation.com/news/academicsminority-more-two-thirds-uk-universities.

Kim, T. (2014). The intellect, mobility and epistemic positioning in doing comparisons and comparative education, Comparative Education 50th Anniversary Special Issue 50(1), 58-72.

Kim, T. (2011). Globalization and Higher Education in South Korea - towards ethnocentric internationalization or global commercialization of higher education? In King, R., Marginson, S. and Naidoo, R. (Eds). Handbook of Globalization and Higher Education, Edward Elgar Publishing Ltd., 286-305.

Kim, T. (2010). Transnational Academic Mobility, Knowledge and Identity Capital, Discourse: Studies in the Cultural Politics of Education. Special Issue on International Academic Mobility, 31(5), 577-592.

Kim, T. (2009). Shifting patterns of transnational academic mobility: A comparative and historical approach, Comparative Education Special Issue on Mobilities and educational metamorphoses: patterns, puzzles, and possibilities 45(3), pp. 387-403.

Kim, T. (2007). Transnational Academic Mobility in a Global Knowledge Economy: comparative and historical motifs (Chapter 18) In Epstein, D., Boden, R., Deem, R., Rizvi, F., and Wright, S. (Eds). The World Yearbook of Education 2008, Geographies of Knowledge and Geometries of Power: Framing the Future of Higher Education, London: Routledge, pp. 319337.

Kim, T. (2005). Internationalisation of Higher Education in South Korea: Reality, Rhetoric, and Disparity in Academic Culture and Identities, The Australian Journal of Education, Special Issue: International Education, edited by Marginson, S., Joseph, C. and Yang, R. 49(1), April, 89-103. 
To be published in Higher Education Special Issue: The New Political Economy of Higher Education: Market logic, performance based stratification and neo-feudal hierarchies, edited by Tilman Reitz et. al. DOI: 10.1007/s10734017-0118-0

Lorenz, C. (2010). Higher Education Policies in the European Union, the 'Knowledge Economy' and Neo-Liberalism, EspacesTemps.net, Travaux, 12.07.2010 http://www.espacestemps.net/articles/higher-education-policies-in-the-european-union/ .

Lyotard, J-F (1984). The Postmodern Condition: A Report on Knowledge, trans. Geoff Bennington and Brian Massumi, Manchester: Manchester University Press, 1984. Trans. of $L a$ Condition postmoderne: rapport sur le savoir (Paris: Minuit, 1979).

Marginson, S. (2016). High Participation Systems of Higher Education, The Journal of Higher Education 87(2), March/April, 243-271.

Marginson, S. (2007). Have global academics flows created a global labour market? In Epstein, D., Boden, R., Deem, R., Rizvi, F., and Wright, S. (Eds). The World Yearbook of Education 2008, Geographies of Knowledge and Geometries of Power: Framing the Future of Higher Education, London: Routledge, pp. 305-318.

Mills, C. Wright (1959). The Sociological Imagination, Oxford and New York: Oxford University Press.

Mock, J., Kawamura, H., and Naganuma, N. (Eds). (2016). The Impact of Internationalization on Japanese Higher Education: Is Japanese Education Really Changing?, Rotterdam: Sense Publishers.

Münch, R. (2014). Academic Capitalism: Universities in the Global Struggle for Excellence, New York and London: Routledge.

Musselin, C. (2005) Le marché des universitaires: France, Allemagne, Etats-Unis, Paris: Presses de Sciences Po $\mid$ Académique.

OECD (2015). Executive summary in Indicators of Immigrant Integration 2015: Settling In, Paris: OECD Publishing (http://www.oecd-ilibrary.org/social-issues-migration-health/indicatorsof-immigrant-integration-2015-settling-in 9789264234024-en).

OECD (2013). International Migration Outlook, Paris: OECD Publishing.

Patterson, O. (1977). Ethnic Chauvnism: The Reactionary Impulse, New York: Stein \& Day.

Pels, D. (2000). The Intellectual as Stranger, London and New York: Routledge.

Polanyi, M. (1966; 2009). The Tacit Dimension, University of Chicago Press: Chicago.

Popper, K. (1976). Unended quest: an intellectual autobiography, Glasgow: Fontana/Collins [Paperback edition]. 
To be published in Higher Education Special Issue: The New Political Economy of Higher Education: Market logic, performance based stratification and neo-feudal hierarchies, edited by Tilman Reitz et. al. DOI: 10.1007/s10734017-0118-0

Rappleye, J. and Vickers, E. (2015). Can Japanese universities really become Super Global?, University World News, 6 November

2015: http://www.universityworldnews.com/article.php?story=20151103154757426.

Reitz, T. (2017). Academic Hierarchies in Neo-Feudal Capitalism: How Status Competition Processes Trust and Facilitates the Appropriation of Knowledge, Higher Education.

Ricoeur, P. (1992) Oneself as Another, Chicago: University of Chicago Press.

Ricoeur, P. (1984). Time and Narrative vol. 1, trans. by Kathleen McLaughlin and David Pellauer, Chicago: University of Chicago Press.

Rosinger, K. O., Taylor, B. J., Coco, L., Slaughter, S. (2016). Organizational Segmentation and the Prestige Economy: Deprofessionalization in High and Low-Resource Departments, The Journal of Higher Education 87(1), 27-54.

Sang, K., Al-Dajani, H. and Özbilgin, M. (2013). Frayed Careers of Migrant Female Professors in British Academia: An Intersectional Perspective, Gender, Work and Organization 20(2), March, 158-171.

Scott, P. (1998). Massification, Internationalization and Globalization. In Scott, P. (Ed.) The Globalization of Higher Education. Buckingham: Society for Research into Higher Education \& Open University Press, 108-129.

Shore, C. and Wright, S. (1999). Audit culture and anthropology: neo-liberalism in British higher education, The Journal of the Royal Anthropological Institute 5(4), 557-575.

Simmel, G. (1908; 1971). The Stranger In Georg Simmel: On Individuality and Social Forms. Selected Writings (Donald N. Levine, Ed. and Intro.). Chicago: The University of Chicago Press, 143-50.

Slaughter, S. and Leslie, L. (1997). Academic Capitalism: Politics, Policies, and the Entrepreneurial University, Baltimore: Johns Hopkins University Press.

Slaughter, S. (2001) Professional Values and the Allure of the Market, Academe 87 (5): 22-26.

Slaughter, S. \& Rhoades, G. (2004). Academic Capitalism and the New Economy: Markets, State and Higher Education, Baltimore: Johns Hopkins University Press.

Teichler, U. (1996). Research on academic mobility and international cooperation in higher education: An agenda for the future In Blumenthal, P., Goodwin, C. and Smith, A. et. al. (eds). Academic Mobility in a Changing World: Regional and Global Trends. London: Jessica Kingsley Publishers, pp. 338-358. 
To be published in Higher Education Special Issue: The New Political Economy of Higher Education: Market logic, performance based stratification and neo-feudal hierarchies, edited by Tilman Reitz et. al. DOI: 10.1007/s10734017-0118-0

Teichler, U. (Ed). The Formative Years of Scholars, Proceedings from a symposium held at the Haga Forum, Stockholm, 9-11 November 2005, London: Portland Press.

Trowler, P., Saunders, M., and Bamber, V. (Eds). (2012). Tribes and territories in the 21stcentury. London : Routledge.

University of Oxford (2016). Equality Report 2014/15, Section B: Staff Equality

Data: https://www.admin.ox.ac.uk/media/global/wwwadminoxacuk/localsites/equalityanddiversi ty/documents/psed/University of Oxford Equality Report 2014-

15 Section_B_Staff_data_FINAL].pdf (Publication Date: 29 January 2016).

Universities UK (2007). Policy briefing, talent wars: The international market for academic staff. London: Universities UK

(http://bookshop.universitiesuk.ac.uk/downloads/Policy\%20Brief\%20Talent\%20Wars.pdf).

Werbner, P., (1999). Global Pathways: Working Class Cosmopolitans and the Creation of Transnational Ethnic Worlds, Social Anthropology, 7(1), 17-35. 